Now Offering a 20\% Discount When a Minimum of Five Titles in Related Subject Areas are Purchased Together

Also, receive free worldwide shipping on orders over US\$ 395.

(This offer will be automatically applied upon checkout and is applicable to print \& digital publications)

Browse Titles (https://www.igi-global.com/search/?p=\&ctid=1\%2c2).

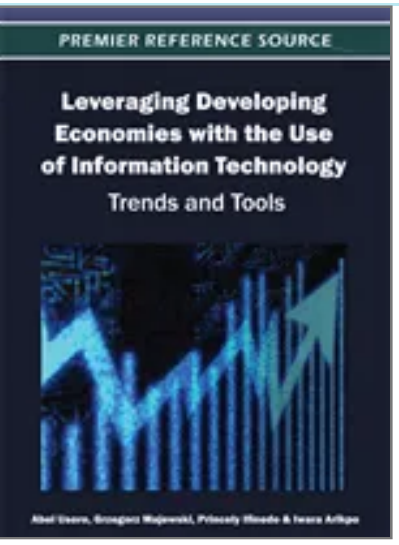

\title{
Integrating Information Communication Technologies (ICT) with Information Literacy \& Library-Use-Instructions in Nigerian Universities
}

Aniebiet I. Ntui (University of Calabar, Nigeria), Eno J. Ottong (University of Calabar, Nigeria) and Abel Usoro (/affiliate/abelusoro/181872/) (University of the West of Scotland, UK)

Source Title: Leveraging Developing Economies with the Use of Information Technology: Trends and Tools (/book/leveragingdeveloping-economies-use-information/61661)

Copyright: (C) 2012

Pages: 11

DOI: 10.4018/978-1-4666-1637-0.ch013

OnDemand PDF

Download:

$\$ 37.50$

() Available

Current Special Offers

Buy Instant PDF Access

Qty: 1 マ $\mathbf{\$ 3 7 . 5 0}$

Add to Cart

Available. Instant access upon order completion.

\section{Abstract}

Curriculum contents in developing economies like Nigeria has the objectives of developing students' higher order thinking skills, ability to acquire and utilize learning sources in the library, develop adequate competence in the use of needed information among others. It should aim as developing technological capability for handling information that would achieve these objectives. This study 
evaluates the information literacy and library-use programmes introduced in Nigerian universities to achieve the aforementioned objectives. An empirical work done on three Nigerian Universities, as a sample, compares their curriculum contents and explores ways that information technology can be integrated into them. Among the study findings is inadequate attention paid to information and technology literacy. One of the study's recommendations is to give adequate attention to information and technology literacy without loading the students with unnecessary library technicalities, as the study found out. The study also presented curriculum structures that can improve the situation.

\title{
Chapter Preview
}

\section{Introduction}

The ultimate goal of education has been argued to be the leading of "individuals to understand how the world functions and help them find new ways to make the world" Konidari (2011). The National policy on education (2004) localizes this goal by specifying that the philosophy and goal of education in Nigeria is functional education, for the promotion of a progressive united Nigeria. To this end, school programmes need to be relevant, purposive and comprehensive. Accordingly, life long education is ensured as the basis of the nation's educational policy. The major goal of Nigeria University system is to teach, research and determine the content of courses. Libraries are becoming ever more important partners for research and teaching, with both print and non-print resources. Nigerian universities are also trying to offer their communities not only hard copies of books and journals but also their electronic forms sometimes organized in databases that are assessable to the readers.

The National University commission recommended that library-use-instruction should be taught under the general studies programme, to ensure that students make use of the enormous resources in the library. In response, Nigerian Universities have introduced and implemented library-use-instruction programme (LUIP) as stipulated by NUC. It is a formally structured programme of activities designed to transmit knowledge and skills about acquisition and utilization of learning resources in the library. Undergraduate students who pass through LUIP, apart from acquiring the knowledge to use library resources should be able to acquire skills that enable them to develop adequate competence in the use of information and become information literate.

Association of College and Research Library, ACRL (2000) puts information literacy as a key component of, and contributor to life long learning. Information literacy is generally defined as having the ability to recognize when information is needed, and then to be able to locate and evaluate appropriate information and use (American Library Association, 1989).

The concern to get undergraduate students in Nigerian Universities properly educated in the utilization of library resources and to acquire information literacy competence has made the university librarians to develop curriculum contents for information literacy and LUI programme. This instruction is taught under the course Use of English/Communication Skills in the General Studies programme in most Nigerian Universities. The focus of the instruction is on 100/200 level (first and second year) undergraduates. The information literacy (IL) and library-use-instructions (LUI) curriculum content is to enable the student utilize the library resources, and have the ability to locate, access, analyse, and evaluate the needed information. A study by Lwehabura (1999) reveals that the course contents of the programme pose problems to users especially freshpersons, with too much technicalities of the library profession which may hinder good assimilation of knowledge. Sanni and Idiodu (2004) study reveals that IL and LUI curriculum contents in Nigerian Universities does not involve the whole information and communication processes, critical thinking skills and ICT concepts. It is against this background that this study sets out to examine the curriculum contents of library-use-instruction and information literacy in Nigeria Universities. The study will also identify the constraints of the programme and suggest measures of integrating ICT into the curriculum.

\section{Complete Chapter List}

\author{
Search this Book: Full text search terms
}

Reset

Editorial Advisory Board

Table of Contents
View Full PDF (/pdf.aspx? tid $=81867 \&$ ptid $=61661 \& \mathrm{ctid}=15 \& \mathrm{t}=$ Editorial Advisory Board\&isxn=9781466616370)

View Full PDF (/pdf.aspx?

$\mathrm{tid}=81868 \& \mathrm{ptid}=61661 \& \mathrm{ctid}=15 \& \mathrm{t}=$ Table of Contents\&isxn=9781466616370) 